\title{
Female breast cancer mortality in Brazil and its regions
}

\author{
Ana Claudia Garabeli Cavalli Kluthcovsky ${ }^{1}$, Thaisa Nogueira Palozi Faria ${ }^{2}$, Fabio Henrique Carneiro², Robson Strona ${ }^{2}$ \\ 1-Department of Medicine, State University of Ponta Grossa, Ponta Grossa, PR, Brazil. \\ 2-Student on the undergraduate Medicine course, State University of Ponta Grossa, Ponta Grossa, PR, Brazil; Scholarship holder from the Araucária Foundation for the Support of Scientific and Technological Development \\ of the State of Paraná.
}

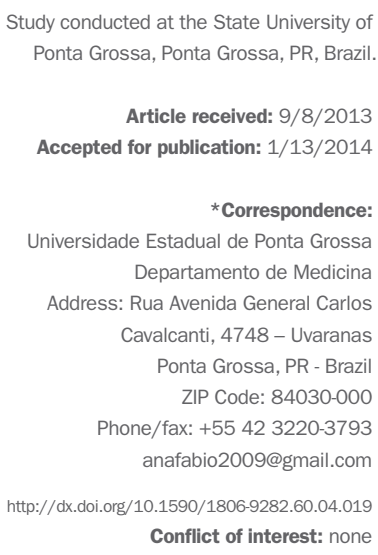

\section{SUMmarY}

Objective: to analyze female breast cancer mortality trends in Brazil and its regions.

Methods: female breast cancer mortality in Brazil and its regions was analyzed using mortality data from the Ministry of Health's Mortality Information System and the National Cancer Institute between 1991 and 2010. The variables analyzed were. proportional mortality from female breast cancer in relation to total deaths in women, mortality rates of the five primary locations of the neoplasms most common in women, and mortality rates for female breast cancer: Linear regression models were estimated to analyze mortality trends:

Results: a growth in proportional mortality due to female breast cancer in Brazil and its regions was observed: In relation to the mortality rates for the five primary types of cancer, breast cancer persisted in first place in Brazil and its regions, except the North region, where cervical cancer was the most frequent: Rising female breast cancer mortality rates were observed for Brazil $(p=0.017)$, Northeastern $(p<0.001)$, North $(p<0.001)$ and the Mid-West $(p=0.001)$, regions, and declining rates for the Southeast region $(\mathrm{p}=0.047)$, and stable rates for the South region.

Conclusion: the results emphasize the importance of the disease in terms of public health in the country, reinforcing the need for early detection and appropriate treatment.

Uniterms: breast neoplasms, mortality, trends, epidemiological studies.

\section{INTRODUCTION}

Among neoplasm, breast cancer is the second most frequent type in the world and the most common among women, not considering non-melanoma skin neoplasms. Furthermore, every year around $23 \%$ of the new cases of cancer in women relate to breast cancer. ${ }^{1}$ It is estimated that 1.38 million women worldwide were diagnosed with breast cancer in 2008, responding for almost one fourth of all cancers diagnosed in women. ${ }^{2}$

52,680 new cases of the disease were expected in Brazil in 2012, with an estimated risk of 52 cases to every 100,000 women. ${ }^{1}$ For the United States, approximately 232,340 new cases of invasive breast cancer are expected in 2013, with 39,620 deaths estimated for the disease. ${ }^{3}$

Cancer in general has been widely considered a disease of developed countries with large financial resources. However, in recent decades, the majority of the global burden of cancer can be observed in developing countries, especially those with few or average resources. According to the World Health Organization, by 2030 we can expect 27 million incident cases of cancer, 17 million cancer-related deaths and 75 million living people with cancer, annually. The greatest effect of this increase will be on countries with low to average incomes. ${ }^{1}$

In Brazil, the incidence rates for breast cancer are in an intermediate range of magnitude in relation to the world. The disease is related to the urbanization process of society, with a higher risk of illness among women with a higher socioeconomic status, and more common among women living in large cities than those in rural areas.

Given this situation and considering the relevance of breast cancer in the context of public health in Brazil and worldwide, the analysis of mortality data is an important sour- 
ce for understanding the disease, and can help to guide the best alternatives for diagnosis, monitoring and treatment.

This study has the objectives of analyzing proportional mortality due to female breast cancer in relation to the total deaths in women, mortality rates for the five primary locations of the neoplasms most common in women, and the mortality rates due to female breast cancer in Brazil and its regions from 1991 to 2010.

\section{Methods}

This is an ecological study using epidemiological methods with delineation of a time series (trends) on studies of mortality due to female breast cancer in Brazil and its regions between the years 1991 and 2010. Data were collected through the Ministry of Health's Mortality Information System $(\mathrm{SIM})^{5}$ and data from the National Cancer Institute, ${ }^{6}$ covering the past twenty years available, from 1991 to 2010 . The data refers to codes 174-175 of International Classification of Diseases, $9^{\text {th }}$ Revision, (ICD-9), ${ }^{7}$ from 1991 to 1995 , and code C50 of the $10^{\text {th }}$ revision (ICD-10), from 1996 to $2010 .{ }^{8}$

The following variables were analyzed:

- Proportional mortality (PM) due to female breast cancer in relation to the total deaths in women, by location of residence, in four-year periods (1991 to 1994, 1995 to 1998,1999 to 2002,2003 to 2006 and 2007 to 2010), for Brazil and its regions. The proportional variation of female breast cancer mortality in Brazil and its regions was also calculated using the proportional mortality in the last four-year period (2007 to 2010) and first four-year period analyzed (1991 to 1994), considering the equation:

Proportional variation $=(\mathrm{PM} 2007$ to $2010 / \mathrm{PM} 1991$ to 1994) $-1 * 100$.

- Mortality rates for the five primary locations of the neoplasms most common in women, age-adjusted using the world population, per 100,000 women, for Brazil and its regions between 1991 and 2010. This covered neoplasms of the lung, trachea and bronchi, esophagus, stomach, colon, rectum, anus and recto-sigmoid junction, the female breast, the cervix, and other locations. ${ }^{6}$

- Mortality rates due to female breast cancer age-adjusted using the world population, per 100,000 women for Brazil and its regions. This rate expresses the number of breast cancer deaths per 100,000 women in the population resident in a determined geographical area in the applicable year.
The mortality rates for the five primary locations of the neoplasms most common in women and the female breast cancer mortality rates analyzed in this study were standardized using the direct method, and age-adjusted using the standardized world population as a reference. $^{6}$

Data analysis was performed by analyzing the absolute and relative frequencies. The mortality trend over time of standardized female breast cancer was analyzed. To do so, simple, linear regression models, ${ }^{9}$ were used where the dependent variable (y) corresponded to mortality rates and the independent variable $(x)$ to the years studied. The linear model was defined as $y=b_{0}+b_{1} x$, where $b_{0}$ corresponds to the average coefficient for the period and $b_{1}$ to the increment (increase or decrease) in the period. The level of significance was $5 \%$. The data were tabulated in Excel 2010. The data was processed using SPSS (Statistical Package for the Social Sciences) version 18.0.

\section{Results}

An increase was observed in the proportion of deaths due to female breast cancer in relation to the total deaths of women in Brazil over time, which moved from 1.8\% of deaths in the four-year period from 1991-1994 to $2.6 \%$ in 2007-2010, with a proportional variation of $39.4 \%$. The proportional mortality for female breast cancer also increased over the time period analyzed in all regions, with greater proportional variations for the Northeast region (increase of 106\%), the North region (increase of $85.2 \%$ ) and the Mid-West region (increase of 60.6\%) (Table 1).

The morality rates for the five primary locations of the neoplasms most common in women, age-adjusted using the world population, per 100,000 women for Brazil and its regions can be seen Table 2. For Brazil, between the years 1991 and 2010, breast cancer persists with the highest mortality rates. The rates for the other four neoplasms varied over the years, with neoplasms of the trachea, bronchia and lungs more common in recent years, followed by colorectal neoplasms. In fourth place were cervical neoplasms, with malignant neoplasms of the stomach in fifth place. Breast cancer remains with the highest mortality rates for Brazilian regions in all years, with the exception of the North region, where cervical cancer displayed higher rates.

For female breast cancer age-adjusted using the world population, per 100,000 women, Brazil shows rates varying from 10.20 (1991) to 12.64 (2006). Among the regions, the highest mortality rates were noted in the Southeast region, with a peak of 14.88 deaths/100,000 women in 1999, followed by the South region with a peak of $14.52 / 100,000$ 
TABLE 1 Number of deaths due to breast cancer (N), proportional mortality (PM) due to breast cancer in relation to total deaths in women and proportional variation of breast cancer mortality for the female population in Brazil and its regions, per four-year period, from 1991 to 2010

\begin{tabular}{|c|c|c|c|c|c|c|c|c|c|c|c|}
\hline \multirow{2}{*}{ Local } & \multicolumn{2}{|c|}{ 1991-1994 } & \multicolumn{2}{|c|}{ 1995-1998 } & \multicolumn{2}{|c|}{ 1999-2002 } & \multicolumn{2}{|c|}{ 2003-2006 } & \multicolumn{2}{|c|}{$2007-2010$} & \multirow{2}{*}{$\begin{array}{l}\text { Variação } \\
(\%)\end{array}$} \\
\hline & $n$ & (PM) & $n$ & (PM) & $n$ & (PM) & $n$ & (PM) & $n$ & (PM) & \\
\hline Brazil & 25,489 & $(1.8)$ & 29,557 & $(2.0)$ & 34,082 & $(2.1)$ & 40,173 & $(2.3)$ & 47,546 & $(2.6)$ & 39.4 \\
\hline Northeast & 3,428 & $(1.0)$ & 4,113 & $(1.1)$ & 5,015 & $(1.3)$ & 7,043 & $(1.6)$ & 9,583 & $(2.1)$ & 106 \\
\hline North & 487 & $(0.8)$ & 622 & $(1.0)$ & 805 & (1.1) & 1,098 & (1.3) & 1,480 & $(1.6)$ & 85.2 \\
\hline Mid-West & 1,044 & (1.5) & 1,296 & $(1.6)$ & 1,679 & (2.0) & 2,143 & $(2.2)$ & 2,664 & $(2.5)$ & 60.6 \\
\hline Southeast & 15,426 & $(2.2)$ & 17,847 & $(2.4)$ & 19,935 & $(2.6)$ & 22,408 & $(2.7)$ & 25,287 & $(2.8)$ & 27.8 \\
\hline South & 5,104 & (2.3) & 5,679 & $(2.3)$ & 6,648 & (2.6) & 7,481 & $(2.7)$ & 8,532 & $(2.9)$ & 25.5 \\
\hline
\end{tabular}

Source: elaborated using date from DATASUS/Ministry of Health.

TABLE 2 Mortality rates of the five most frequent primary neoplasm locations, age-adjusted based on the world population, per 100,000 women, in Brazil and regions between 1991 and 2010

\begin{tabular}{|c|c|c|c|}
\hline \multirow[t]{3}{*}{ Location } & \multirow[t]{3}{*}{$\begin{array}{l}\text { Neoplasms by order of greater } \\
\text { mortality }\end{array}$} & \multicolumn{2}{|c|}{$\begin{array}{l}\text { Mortality } \\
\text { rates }\end{array}$} \\
\hline & & Start & End \\
\hline & & 1991 & 2010 \\
\hline \multirow[t]{5}{*}{ Brazil } & $1^{\text {st }}$ Breast & 10.21 & 11.51 \\
\hline & $2^{\text {nd }}$ Trachea, bronchi and lungs & 5.03 & 7.41 \\
\hline & $3^{\text {rd }}$ Colorectal & 4.43 & 5.91 \\
\hline & $4^{\text {th }}$ Cervical & 4.98 & 4.54 \\
\hline & $5^{\text {th }}$ Stomach & 5.78 & 4.11 \\
\hline \multirow[t]{5}{*}{ Northeast } & $1^{\text {st }}$ Breast & 4.98 & 9.28 \\
\hline & $2^{\text {nd }}$ Trachea, bronchi and lungs & 2.11 & 5.55 \\
\hline & $3^{\text {rd }}$ Cervical & 4.33 & 2.11 \\
\hline & $4^{\text {th }}$ Stomach & 2.48 & 3.73 \\
\hline & $5^{\text {th }}$ Liver and intrahepatic bile ducts & 1.95 & 3.17 \\
\hline \multirow[t]{5}{*}{ North } & $1^{\text {st }}$ Cervical & 6.86 & 9.19 \\
\hline & $2^{\text {nd }}$ Breast & 3.49 & 6.22 \\
\hline & $3^{\text {rd }}$ Trachea, bronchi and lungs & 3.61 & 4.9 \\
\hline & $4^{\text {th }}$ Stomach & 5.6 & 4.59 \\
\hline & $5^{\text {th }}$ Colorectal & 1.72 & 3.17 \\
\hline \multirow{5}{*}{$\begin{array}{l}\text { Mid- } \\
\text { West }\end{array}$} & $1^{\text {st }}$ Breast & 9.05 & 10.85 \\
\hline & $2^{\text {nd }}$ Trachea, bronchi and lungs & 5.97 & 7.61 \\
\hline & $3^{\text {rd }}$ Colorectal & 3.39 & 6.38 \\
\hline & $4^{\text {th }}$ Cervical & 6.06 & 5.86 \\
\hline & $5^{\text {th }}$ Stomach & 5.41 & 3.78 \\
\hline \multirow{5}{*}{ Southeast } & $1^{\text {st }}$ Breast & 13.3 & 12.85 \\
\hline & $2^{\text {nd }}$ Trachea, bronchi and lungs & 5.84 & 7.55 \\
\hline & $3^{\text {rd }}$ Colorectal & 5.83 & 7.24 \\
\hline & $4^{\text {th }}$ Stomach & 7.43 & 4.2 \\
\hline & $5^{\text {th }}$ Cervical & 4.7 & 3.6 \\
\hline \multirow[t]{5}{*}{ South } & $1^{\text {st }}$ Breast & 12.19 & 13.24 \\
\hline & $2^{\text {nd }}$ Trachea, bronchi and lungs & 7.87 & 10.78 \\
\hline & $3^{\text {rd }}$ Colorectal & 6.43 & 7.48 \\
\hline & $4^{\text {th }}$ Pancreas & 3.54 & 4.85 \\
\hline & $5^{\text {th }}$ Stomach & 6.95 & 4.45 \\
\hline
\end{tabular}

Source: elaborated using data from the National Cancer Institute (INCA). women in 2006. The Mid-South region showed intermediate mortality rates, with the lowest at 7.61 deaths $/ 100,000$ women in 1992, and 12.38 deaths/100,000 women in 2006. The Northeast and North regions showed the lowest morality rates, with peaks of 9.59 deaths/100,000 in 2006 and 7.35 in 2008, respectively.

Table 3 presents the start and end female breast cancer mortality rates, and mortality rate trends, with their respective linear regression models. A significant trend for rising female breast cancer mortality rates were observed for Brazil $(p=0.017)$, the Northeast $(p<0,001)$, North $(p<0,001)$ and Mid-West $(p=0.001)$ regions, with declining rates for the Southeast region $(\mathrm{p}=0.047)$, and stable rates for the South region.

\section{Discussion}

The proportional mortality for neoplasms in Brazil has grown considerably in recent decades, accompanying the growth in mortality due to circulatory system disease and external causes, at the same time in which death due to infectious and parasitic diseases has decreased, portraying the epidemiological and demographic transition verified in the country. ${ }^{10}$

The analysis of the results of this study shows that proportional mortality due to female breast cancer in relation to total deaths of women increased over the four-year periods analyzed in Brazil and its regions, with greater proportional variations in the Northeast, North and Mid-West regions.

Non-communicable chronic diseases, especially cardiovascular disease, cancer, chronic respiratory disorders and diabetes represent the greatest burden for morbidity and mortality in Brazil. Despite the mortality standardized for cardiovascular and respiratory diseases having decreased in recent years, the mortality rates for cancer and diabetes have not shown many changes. ${ }^{11}$ 
TABLE 3 Mortality rates due to female breast cancer age-adjusted based on the world population, per 100,000 women, in Brazil and regions between 1991 and 2010

\begin{tabular}{|c|c|c|c|c|c|c|}
\hline \multirow[t]{3}{*}{ Location } & \multicolumn{2}{|c|}{ Mortality rates } & \multirow[t]{3}{*}{ Model } & \multirow[t]{3}{*}{$\mathbf{R}^{2}$} & \multirow[t]{3}{*}{$\mathbf{p}$} & \multirow[t]{3}{*}{ Trend } \\
\hline & Start & End & & & & \\
\hline & 1991 & 2010 & & & & \\
\hline Brazil & 10.21 & 11.51 & $y=10.754+0.0513 x$ & 27.7 & 0.017 & Growing \\
\hline Northeast & 4.98 & 9.28 & $y=4.2412+0.2499 x$ & 88.5 & $<0,001$ & Growing \\
\hline North & 3.49 & 6.22 & $y=3.9892+0.1427 x$ & 71.8 & $<0.001$ & Growing \\
\hline Mid-West & 9.05 & 10.85 & $y=8.3568+0.1352 x$ & 46.3 & 0.001 & Growing \\
\hline Southeast & 13.3 & 12.85 & $y=14.441-0.0569 x$ & 20.1 & 0.047 & Declining \\
\hline South & 12.19 & 13.24 & $y=13.593-0.0146 x$ & 1.30 & 0.628 & Stationary \\
\hline
\end{tabular}

Source: Elaborated using date from DATASUS/Ministry of Health and the INCA

Among neoplasms in women, breast cancer represents an important cause of mortality and hospital morbidity with a large demand for hospitalization and consequent high clinical care costs. ${ }^{12}$ In fact, mortality due to cancer, specifically breast cancer, continues a major problem for Public Health that needs to be solved..$^{13}$

Mortality in the five primary locations of the most frequent cancers in women, age-adjusted between 1991 and 2010, was highest for breast cancer, which persists in absolute first place in Brazil and its regions, in all years, except for the North region, where cervical cancer showed higher rates.

On the other hand, other countries have shown a different pattern than Brazil in relation to the mortality rates for the most frequent neoplasms in women. In the United States over the last twenty-five years, bronchial and lung cancer has presented higher age-adjusted mortality rates in women, followed by breast cancer and colorectal cancer, both presenting a progressive fall in mortality. ${ }^{3}$ Also, in the United Kingdom, breast cancer is currently the second cause of death due to cancer in women, after lung cancer. ${ }^{14}$ Increases in the mortality rate due to lung cancer in women have also been seen in Latin American countries $^{15}$ and other countries worldwide. ${ }^{16}$

In the present study, for Brazil and the South, Southeast and Mid-West regions, the three neoplasms with the highest mortality rates were breast cancer, bronchial and lung cancer, and colorectal cancer, in this order. However, specifically for the South region, it appears that there is a trend for stabilization of the mortality rate due to breast cancer and an increase in neoplasms of the trachea, bronchia and lung. If this trend persists over the coming years, perhaps the higher mortality rates due to neoplasms in women in the South region will follow the pattern of the countries cited above, with tracheal, bron- chial and lung cancer in first place. A trend for an increase in lung cancer mortality rates in women has already been seen in a study conducted in Rio Grande do Sul, between 1979 and $1995 .{ }^{17}$ This trend towards increase lung cancer mortality in the South region may be a reflection of the prevalence of smoking among women, given that the greatest prevalence of female smokers aged 18 or over in the Brazilian capitals was found in Porto Alegre (21\%), followed by Curitiba (17\%), with Florianópolis in $9^{\text {th }}$ place with a prevalence of $11 \% .{ }^{18}$

The analysis of female breast cancer mortality trends demonstrated a significant increase in mortality for Brazil in the Northeast, North and Mid-West regions, a decrease for the Southeast region, and stationary trend for the South. Other studies conducted in Brazil have demonstrate a trend toward increased breast cancer mortality over the years, such as that realized in the metropolitan region of the cities in Baixada Santista between 1980 and $1999 ;{ }^{19}$ also in the State of Espírito Santo from 1980 to $2007^{20}$ and for the capitals and interior of Brazil between 1980 and $2006 .^{21}$

Contrarily, the female breast cancer mortality rates have decreased in the United States since 1989, mainly among younger women. From 2005 to 2009 there was a decrease of $3 \%$ per year in women aged less than 50 , and a $2 \%$ decrease per year in those aged 50 or more. The reduction in these breast cancer related deaths reflects improved early detection of the disease, advancements in treatment, and possible decrease in its incidence, a result of the decline in hormone replacement therapy. ${ }^{3}$

A decrease in mortality from breast cancer was also observed in young and middle-aged women in Spain from 1993 to 2007, although it remained stable for older women. ${ }^{22}$ In Portugal, there was a decrease in mortality for this disease at $2 \%$ per year between 1992 and $2002 .{ }^{23} \mathrm{Sin}-$ 
ce a peak in the late 1980s, mortality rates from breast cancer have also reduced by almost $40 \%$ in the UK, and in the last 10 years the mortality rates due to breast cancer have fallen by almost $20 \% \cdot{ }^{14}$

The trend of reduced mortality in European countries is attributed to screening via mammography, the implementation of effective hormonal treatments, chemotherapy, and advances in surgical treatment and radiotherapy. These factors have clearly contributed to the increased survival in breast cancer in Europe. ${ }^{24}$

In the case of Brazil, difficulties accessing services for early diagnosis, delays in diagnosis and the time interval between diagnosis tests and suitable breast cancer treatment may be factors that compromise the progression of the disease. In a study of 68 women with breast cancer at a public hospital, delays were noted at various stages of the diagnosis and oncological treatment, especially in the interval between mammography and realization of the biopsy. ${ }^{25}$ Furthermore, the delay in confirming the diagnosis of breast lesions in women attending a SUS reference center was observed in another study, and that was associated with the presence of symptoms, the long interval between the onset of symptoms and the first assessment, and between onset of symptoms and diagnostic confirmation. ${ }^{26}$

In a study on trends in breast cancer mortality in Mexico between 1980 and 2009 regional disparities were observed. It was noted that, although the number of deaths from this cause had gradually increased over time nationwide, in some states of the country this increase was extremely significant. ${ }^{27}$ In Portugal, there was a change in breast cancer mortality since the beginning of the 1990s, with sharper declines in districts with higher mortality rates. The authors considered that improvements in early detection of the disease and access to effective treatments could justify this change, but the characteristics of the access, screening and care of patients in different Portuguese districts would be essential for understanding differences observed at regional level. ${ }^{23}$

Therefore, some differences between the regions in this study could be partially responsible for the variations in rates, such as socioeconomic conditions, lifestyle habits, obstetric history, age at menarche and menopause, hormone therapy, breastfeeding, exams to control breast cancer, and more. As an example of these differences, we can cite the proportion of the female population aged 50-69 years, which reported having performed their last mammogram in the past two years, which was greater in the Southeast (63.8\%), followed by the South (55.1\%), Mid-West (52.4\%), Northeast $(39.8 \%)$ and North (35.3\%) regions. In addition, $62.8 \%$ of wo- men in the Northern region and $59.9 \%$ in the Northeast region had never had a mammogram. ${ }^{28}$

In a review on the influence of socioeconomic inequalities on breast cancer, it was observed that most studies showed a relationship between socioeconomic status and the incidence and prognosis of breast cancer. Socioeconomic deprivation could be responsible for the increased risk of mortality from breast cancer in AfricanAmerican and Hispanic patients, as they are more prone to late diagnosis of the disease than white American patients. Furthermore, among white women, social deprivation is related to a worse breast cancer prognosis. ${ }^{29}$

In this study, perhaps the striking socioeconomic inequalities in different regions of Brazil have an influence on breast cancer mortality trends. The Southeast and South regions, despite being the regions with the highest mortality rates, displayed trends of decreasing and stationary mortality, respectively, and were the regions of the country whose States had the best Human Development Indexes (HDI). ${ }^{30}$

On the other hand, the Mid-West region, with a growing trend of mortality, had lower development indexes, and the North and Northeast regions, with the lowest mortality rates, had growing trends of mortality and the worst human development indexes. ${ }^{30}$

Disparities related to the burden of cancer in different population segments may be defined in socioeconomic, ethnicity, residential, gender and sexual behavior terms. The causes of health disparities within each of these population segments are complex and include the interrelation of social, economic, cultural and health systems factors. Besides these, genetic factors, inequalities in work, health, income, education, housing, standa ${ }^{\text {rd }}$ of living, poor access to quality preventive methods against cancer, early detection and adequate treatment should be higlighted. ${ }^{3}$

Considering that Brazil is a country with great regional diversity, including socioeconomic, social, and cultural factors and those related to the available health services, important differences are expected in relation to the epidemiological scenario of the diseases, including mortality patterns observed in this breast cancer study. These regional variations may also reflect the incidence of cancer arising from the heterogeneous profile of exposure to different lifestyles in the population and risk and protective factors for cancer.

The geographical pattern of differences in the quality of data from the Mortality Information System should also be taken into account, as noted by the high proportion of ill-defined causes of death in the North and Nor- 
theast regions, despite the improvement seen in the last decade. ${ }^{10}$

Thus, in addition to reflecting differences in the incidence of cancer and its relationship to lifestyle, risk factors and the quality of information, regional variations also reflect mortality patterns through differences in conditions for access, use and performance of health services, which are important components of the Brazilian population's living conditions. ${ }^{10}$

Given this situation, it is expected that prevention actions against risk factors, lifestyles and screening for breast cancer, in addition to appropriate treatment, will be expanded within the target population.

\section{Conclusion}

Mortality caused by breast cancer continues to be a major problem for Brazil from the perspective of its proportion in relation to total deaths among women, mortality due to various types of cancer, and the time trend of mortality. When the mortality rates are analyzed among the different regions, important differences can be observed, with decreased or stabilized rates in regions with higher levels of development and rate increases in those with lower levels of development, emphasizing the importa nce of primary and secondary prevention of the disease, considering equality in healthcare.

The analysis of the data presented may help health professionals and managers to define more complete conduct and health policies, psychosocial interventions and allocation of resources focused on this disease, with priority for regions with lower socioeconomic development in the country.

\section{Resumo}

Câncer de mama feminino: análise da mortalidade no Brasil e regiões.

Objetivo: analisar a evolução da mortalidade por câncer de mama feminino nas regiões do Brasil.

Métodos: foi analisada a mortalidade por câncer de mama feminino nas regiões do país, com dados do Sistema de Informações sobre Mortalidade do Ministério da Saúde e do Instituto Nacional do Câncer, entre 1991 e 2010. As variáveis analisadas foram: mortalidade proporcional por câncer de mama feminino em relação ao total de óbitos em mulheres; taxas de mortalidade das cinco localizações primárias das neoplasias mais frequentes em mulheres; e taxas de mortalidade por câncer de mama feminino. Modelos de regressão linear foram estimados para analisar a tendência de mortalidade.
Resultados: foi observado o crescimento da mortalidade proporcional por câncer de mama feminino para as regiões brasileiras. Com relação às taxas de mortalidade das cinco localizações primárias de câncer mais frequentes, o câncer de mama é o que persiste em primeiro lugar nas regiões e no Brasil, com exceção da região Norte, onde o câncer de colo do útero foi o mais frequente. Observou-se tendência significativa de aumento das taxas de mortalidade por câncer de mama no Brasil $(\mathrm{p}=0,017)$ e nas regiões Nordeste $(\mathrm{p}<0,001)$, Norte $(\mathrm{p}<0,001)$ e Centro-Oeste $(\mathrm{p}=0,001)$, de diminuição na região Sudeste $(\mathrm{p}=$ 0,047) e estacionária na região Sul.

Conclusão: os resultados encontrados enfatizam a importância da doença em termos de saúde pública no país, reforçando a necessidade da detecção precoce e do tratamento adequado.

Unitermos: neoplasias da mama; mortalidade; tendências; estudos epidemiológicos.

\section{References}

1. Brasil. Ministério da Saúde. Instituto Nacional de Câncer (INCA). Coordenação Geral de Ações Estratégicas. Coordenação de Prevenção e Vigilância. Estimativa 2012: incidência de câncer no Brasil. Rio de Janeiro: Inca; 2011

2. Ferlay J, Shin HR, Bray F, Forman D, Mathers C, Parkin DM. GLOBOCAN 2008. v.1.2 Cancer incidence and mortality worldwide. IARC Cancer Base $N^{\circ}$ 10. Lyon: International Agency for Research on Cancer; 2010. [cited 2013 jun 20]. Available from: http://globocan.iarc.fr.

3. American Cancer Society. Cancer Facts \& Figures; 2013. [cited 2013 jun 16]. Available from: http://www.cancer.org/acs/groups/content/@ epidemiologysurveilance/documents/document/acspc-036845.pdf

4. Brasil. Ministério da Saúde. Instituto Nacional de Câncer (INCA). Coordenação de prevenção e vigilância. Câncer no Brasil: dados dos registros de base populacional. Rio de Janeiro: INCA; 2010. v.4.

5. Brasil. Ministério da Saúde. Departamento de Informática do Sistema Único de Saúde [citado 5 jun 2013]. Available from: http://www2.datasus.gov.br/ DATASUS/index.php.

6. Brasil. Ministério da Saúde. Instituto Nacional de Câncer (INCA). Atlas de mortalidade por câncer; 2013 [citado 22 fev 2013]. Available from: http:// mortalidade.inca.gov.br/Mortalidade/index.jsp.

7. Organização Mundial da Saúde (OMS). Classificação internacional das doenças. $9^{\text {a }}$ revisão (CID-9). São Paulo: EdUSP; 1993.

8. Organização Mundial da Saúde (OMS). Classificação internacional das doenças e problemas relacionados à saúde. $10^{a}$ revisão (CID-10). São Paulo: EdUSP; 1999.

9. Kleinbaum DG, Kupper LL, Muller KE, Nizam A. Applied regression analysis and other multivariable methods. $3^{\text {rd }}$ ed. Pacific Grove: Duxbury Press; 1988.

10. Brasil. Ministério da Saúde. Instituto Nacional de Câncer (INCA). A Situação do câncer no Brasil. Rio de Janeiro: INCA; 2006.

11. Duncan BB, Chor D, Aquino EML, Bensenor IM, Mill JG, Schmidt MI, et al. Doenças crônicas não transmissíveis no Brasil: prioridade para enfrentamento e investigação. Rev Saúde Pública. 2012;46(1):126-34.

12. Boing AF, Vargas SAL, Boing AC. A carga das neoplasias no Brasil: mortalidade e morbidade hospitalar entre 2002-2004. Rev Assoc Med Bras. 2007;53(4):317-22.

13. Paulinelli RR, Freitas JR, Curado MP, Souza AA. A situação do câncer de mama em Goiás, no Brasil e no mundo: tendências atuais para a incidência e a mortalidade. Rev Bras Saúde Mater Infant. 2003;3(1):17-24.

14. Cancer Research UK Statistics. Breast Cancer. Cancer Statistics. Key Facts. 2013 [cited 2013 jun 16]. Available from: CS_KF_BREAST http://www. cancerresearchuk.org/cancer-info/cancerstats/keyfacts/breast-cancer/. 
15. Bosetti C, Malvezzi M, Chatenoud L, Negri E, Levi F, La Vecchia C. Trends in cancer mortality in the Americas, 1970-2000. Ann Oncol. 2005;16(5):489-501.

16. Liaw YP, Huang YC, Lien GW. Patterns of lung cancer mortality in 23 countries: Application of the age-period-cohort model. BMC Public Health. 2005;5(1):22.

17. Hallal ALC, Gotlieb SL, Latorre MRDO. Evolução da mortalidade por neoplasias malignas no Rio Grande do Sul, 1979-1995. Rev Bras Epidemiol. 2001;4(3):168-75.

18. Brasil. Ministério da Saúde. Secretaria de Vigilância em Saúde, Secretaria de Gestão Estratégica e Participativa. Vigitel Brasil 2011: vigilância de fatores de risco e proteção para doenças crônicas por inquérito telefônico. Brasília (DF): Editora do Ministério da Saúde; 2012.

19. Zago A, Pereira LAA, Braga ALF, Bousquat A. Mortalidade por câncer de mama em mulheres na Baixada Santista, 1980 a 1999. Rev Saúde Pública. 2005;39(4):641-5.

20. Felix JD, Castro DS, Amorim MHC, Zandonade E. Tendência da mortalidade por câncer de mama em mulheres no estado do Espírito Santo, no período de 1980 a 2007. Rev Bras Cancerol. 2011;57(2):159-66.

21. Silva GA, Gamarral CJ, GirianelliI VR, Valente JG. Tendência da mortalidade por câncer nas capitais e interior do Brasil entre 1980 e 2006. Rev Saúde Pública. 2011;45(6):1009-18.

22. Álvaro-Meca A, Debón A, Gil Prieto R, Gil de Miguel Á. Breast cancer mortality in Spain: Has it really declined for all age groups? Pulic Health. 2012;126:891-5.

23. Bastos J, Barros H, Lune N. Evolução da mortalidade por Cancro da Mama em Portugal (1955-2002). Acta Med Port. 2007;20(1):139-44.
24. Autier P, Boniol M, La Vecchia C, Vatten L, Gavin A, Henry C, et al. Disparities in breast cancer mortality trends between 30 European countries: retrospective trend analysis of WHO mortality database. Br Med J. 2010;341:c3620.

25. Trufelli DC, Miranda VC, Santos MBB, Fraile NMP, Pecoroni PG, Gonzaga SFR, et al. Análise do atraso no diagnóstico e tratamento do câncer de mama em um hospital público. Rev Assoc Med Bras. 2008;54(1):72-6.

26. Rezende MCR, Koch HA, Figueiredo JÁ, Thuler LC. Causas do retardo na confirmação diagnóstica de lesões mamárias em mulheres atendidas em um centro de referência do Sistema Único de Saúde no Rio de Janeiro. Rev Bras Ginecol Obstet. 2009;31(2):75-91

27. De la Vara-Salazar E, Suárez-López L, Ángeles-Llerenas A, Torres-Mejía G, Lazcano-Ponce E. Tendencias de la mortalidade por cáncer de mama en México, 1980-2009. Salud Pública de México. 2011;53(5):385-93.

28. Brasil. Ministério da Saúde. Rede Interagencial de Informações para a Saúde. Indicadores e Dados Básicos, Brasil, 2011. Indicadores de cobertura. [cited 31 July 2013]. Available from: http://tabnet.datasus.gov.br/cgi/tabnet. exe?idb2011/f2301.def.

29. Vona-Davis L, Rose DP. The influence of socioeconomic disparities on breast cancer tumor biology and prognosis: a review. J Womens Health. 2009; 18(6):883-93.

30. Programa das Nações Unidas para o Desenvolvimento. Atlas do desenvolvimento humano do Brasil [citado 11 ago 2013]. Available from: http://www.pnud.org.br/IDH/Atlas2013.aspx?indiceAccordion=1\&li=li_ Atlas2013. 